\title{
Towards developing of Industrial Learning Organizations in the city of Lima - Peru
}

\author{
DOI: $10.46932 /$ sfjdv2n1-003
}

Received in: November 1st, 2020

Accepted in: December 30th, 2020

\section{César Antonio Porras Ramírez}

Professor at Universidad Privada Norbert Wiener, Av. Petit Thouars 2021, Lince, Perú.

E-mail: cporrasramirez@yahoo.com

\begin{abstract}
In order to generate practical data that deepens the investigations regarding learning organizations, in the present research work the dimensions or categories of the model of learning organizations were described, measured and compared with the characteristics of three industrial companies in the city of Lima. To obtain data, the researcher proposed an instrument called "Study of the Industrial Learning Organization"; the results showed that companies studied do not fit to the model of learning organizations, because the company of plastics obtained an average score of 4.14, the metalworking 4.09 and the electric 3.77; requiring a minimum score of 5 out of 6 to qualify as an industrial learning organization. It is important to note that all the evaluated industries obtained negative scores in the category of personal domain and leadership that in conjunction with systemic thinking are considered key aspects in order to become a learning organization; therefore, it is essential that each of the Industrial companies reassess their positions and leadership characteristics taking into account that for a learning organization, leaders must possess qualities of service, of teacher and designer of new realities adapted to the continuous local and global changes, turning their organizations into environments of continuous learning.
\end{abstract}

Keywords: learning organization, organizational learning, systemic thinking, leadership.

\section{RESUMEN}

A fin de generar datos prácticos que profundicen las investigaciones respecto a las organizaciones inteligentes, en la presente investigación se describió, midió y comparó las dimensiones o categorías del modelo de organizaciones inteligentes con las características de tres empresas industriales de la ciudad de Lima. Los datos fueron obtenidos mediante el empleo del instrumento de investigación denominado "Estudio de la Organización Industrial Inteligente" propuesta por el autor; los resultados mostraron que las empresas estudiadas no se ajustan al modelo de organizaciones inteligentes, debido a que la empresa de la industria de plásticos obtuvo un puntaje promedio de 4.14, la metalmecánica 4.09 y la eléctrica 3.77, requiriéndose un puntaje mínimo de 5 sobre 6 para ser calificada como organización industrial inteligente. Es importante notar que las empresas evaluadas obtuvieron puntajes negativos en la categoría de dominio personal y liderazgo que, conjuntamente con el pensamiento sistémico son considerados aspectos claves para llegar a ser o transformarse en una organización inteligente; por ello, se hace imprescindible que cada una de las empresas reevalúe su posición y características de liderazgo teniendo en cuenta que para una organización inteligente, los líderes deben poseer cualidades de servicio, de maestro y de diseñador de nuevas realidades adaptadas a los continuos cambios locales y globales, convirtiendo sus organizaciones en ambientes de continuo aprendizaje.

Palabras clave: organización inteligente, aprendizaje organizacional, pensamiento sistémico, liderazgo. 


\section{INTRODUCTION}

The demands of the external environment and globalization during the last decades have promoted organizations to change, thus, in the eighties, quality centers were created to promote total quality management in organizations; later, in the nineties, leading companies had to reengineer their organizations and, since the end on the nineties, the model of learning organizations began to be developed with the creation of innovation centers that respond to the new environment of change and interdependence.

A learning organization is "an organization that learns and continually expands its capacity to create its future (...) combines adaptive learning with generative learning, learning that increases our creative capacity" (Senge, 1990). Based on the proposal of the scientist of the Massachusetts Institute of Technology, Peter Senge, considered the father of the learning organization; in the last decades, there has been a lot of literature that refers to what a learning organization is; thus, many researches have proposed different elements or components for learning organization according to the type of organization they wish to study, hence, the author, in a previous investigation (Porras, 2010), agreed with the proposal of Osterhaus (cited by Porras, 2010) that the learning organization model can be composed of seven categories or organizational factors and management practices: Shared mission/vision, teamwork and learning, mental models and organizational culture, shared knowledge, competencies and abilities, personal dominance and leadership and, systemic thinking. (See figure $\mathrm{N}^{\circ} 1$ ).

Figure 1: Learning Organizations Model

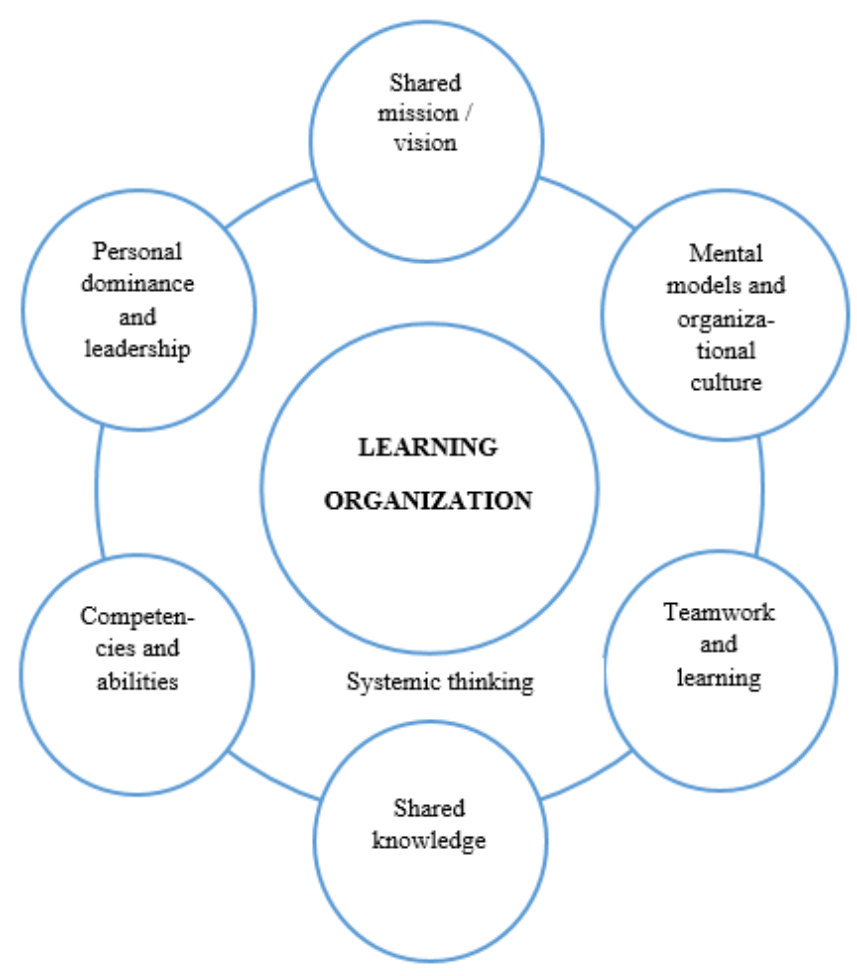


As mentioned for more than two decades, worldwide there is a lot of interest in studying learning organizations; thus, in a study of a unit of the special operations forces of the United States of America that is considered a learning organization, it is shown that the ability to learn as an organization is very important in the long-term perspective (Franta, 2012). In addition, in Asian culture, the learning organization model proposed by Peter Senge was measured and applied, demonstrating the applicability of its theoretical constructs (Park, 2008). In Finland, various learning organizations were explored and analyzed, trying to delineate the form of a holistic learning organization based on a structure of related and interconnected elements at two levels: individual and organizational (Moilanen, 2005). A study by the University Of Ottawa School Of Management examines the relationship between the learning capacity of organizations and its potential impact on the performance of the company, as the literature shows that learning organizations are high-performance organizations (Goh \& Ryan, 2002).

In Peru, research on this topic is very scarce and most of the publications cover mainly theoretical issues, appraisals, opinions and points of view that lack quantitative measurements, therefore, this work generates practical data to allow proposing organizational development interventions for have companies open to continuous learning, recognizing that "a learning organization is an organization open to change, capable of creating, acquiring, applying and transferring knowledge to increase its creative and innovative capacity, designing its own successful and sustained future" (Porras, 2010).

\section{METHODOLOGY}

Based on the objective of measuring the level of the industrial sector of the city of Lima according to the learning organization model, the research instrument "study of industrial learning organization" was applied, whose technical sheet is shown in table 1.

With the research instrument, the levels of each of the seven categories or dimensions of the learning organization were measured, obtaining individual indices for each of them and a total index of the learning organization.

The research design was quasi-experimental: Ox r Oy; being the type of applied research, descriptive-explanatory level and following a quantitative-comparative analysis methodology to contrast the results according to the type of company analyzed.

Table 1: Technical file of the research instrument

\begin{tabular}{|l|r|r|}
\hline & Original version & Modified version \\
\hline Name & $\begin{array}{r}\text { Estudio de la organización } \\
\text { inteligente }\end{array}$ & $\begin{array}{r}\text { Estudio de la organización } \\
\text { industrial inteligente }\end{array}$ \\
\hline Author & César A. Porras & César A. Porras \\
\hline Origin & Universidad Ricardo Palma & Universidad Peruana de las \\
& Américas \\
\hline Country & Peru & Peru \\
\hline
\end{tabular}




\begin{tabular}{|l|r|r|}
\hline Year of publication & 2010 & 2018 \\
\hline Language & Spanish & Spanish \\
\hline Application area & Business organizations & Industrial organizations \\
\hline Validity and reliability & $\begin{array}{r}\text { Judges“ criterion, Aiken's V } \\
\text { coefficient method (average 0.90). }\end{array}$ & Cronbach's alpha: 0.955 \\
\hline Data collection method & $\begin{array}{r}\text { Questionnaire with a 7-point Likert- } \\
\text { type scale interval }\end{array}$ & $\begin{array}{l}\text { Questionnaire with a 6-point Likert- } \\
\text { type scale interval }\end{array}$ \\
\hline Questionnaire questions & 31 & 31 \\
\hline Demographic questions & 6 & 6 \\
\hline
\end{tabular}

The investigated population comprised a group of three companies from the industrial sector of the city of Lima; they were one from the plastics industry, one from the metalworking industry and another from the electrical industry.

The sample design was non-probabilistic-intentional, since the sample of the investigated industries was determined by the opportunity and access to key informants of each one of them.

\section{RESULTS}

\subsection{DEMOGRAPHIC DATA ANALYSIS}

Analyzes of the demographic data were carried taking as reference the type of industry to which the study participants belonged; thus, in figure 2 it is observed that new employees between zero and five years of service comprise the largest segment of respondents from the plastic and metalworking industry and in the electrical industry the majority reach up to fifteen years.

Figure 2: Years of service by type of industry

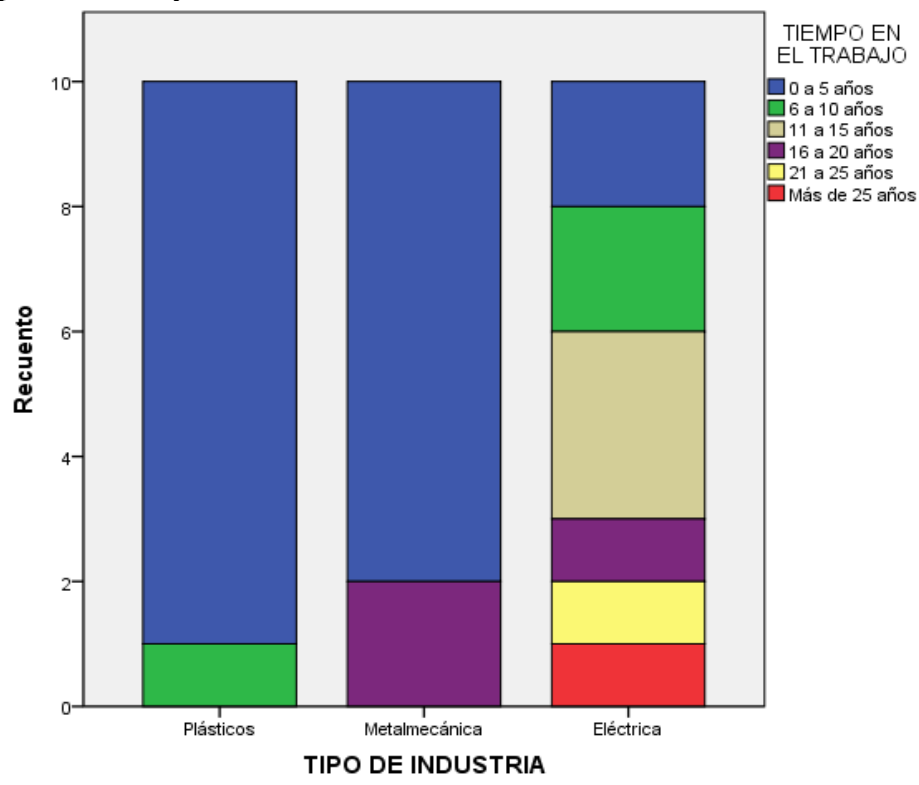

In figure 3, the years of experience by type of industry of the study participants are shown, which shows that for the plastics and metalworking industries most of the personnel do not exceed five years of 
experience, while for the electrical industry more than eighty percent of the staff have more than six years of experience.

Figure 3: Experience in current position

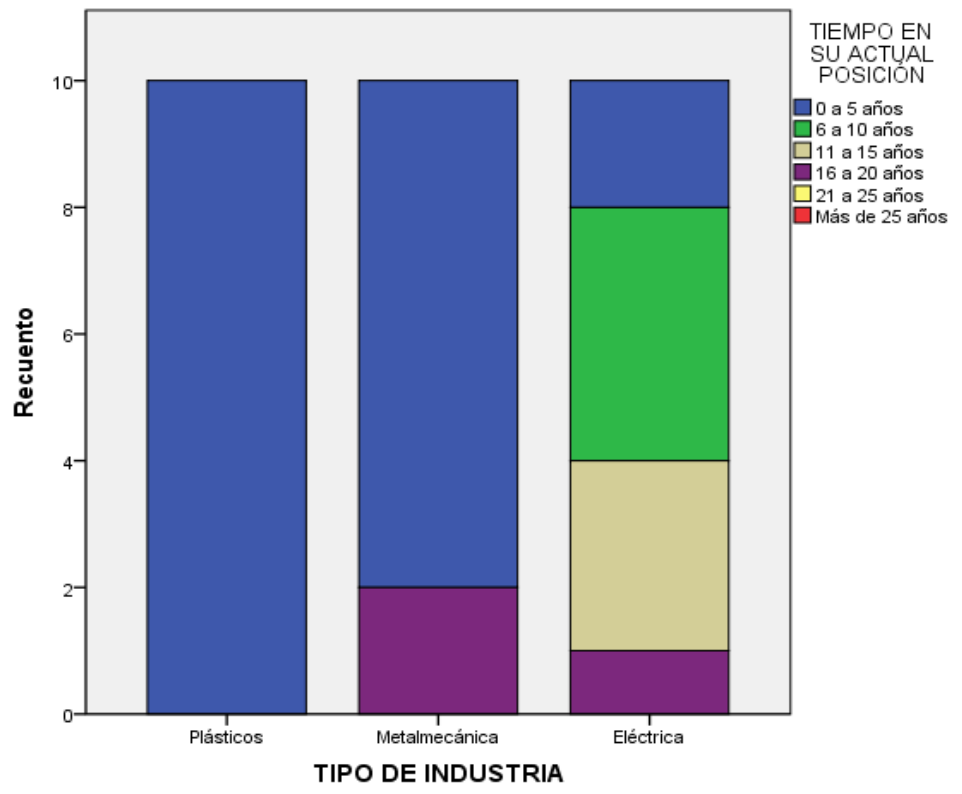

Regarding the supervisory responsibilities in the three industries they are different, whereas in the plastics industry only 10 percent of supervisors were surveyed, in the metalworking industry 90 percent of supervisors were surveyed and in the electrical industry, 50 percent of all respondents were supervisors (see figure 4).

Figure 4: Supervisory responsibilities

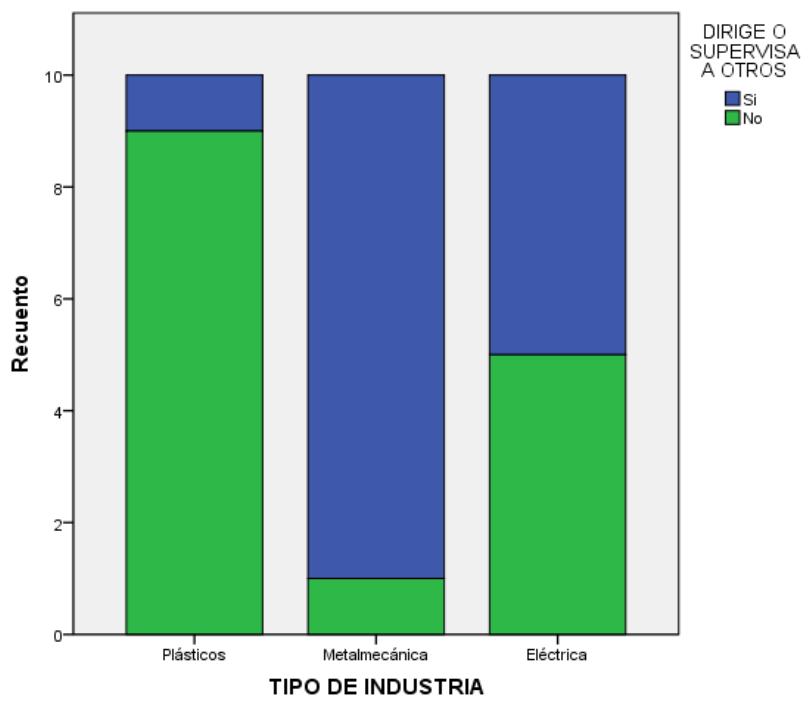


Figure 5 shows the gender representation of the study participants, where it is observed that overall, more than 80 percent of the respondents from the three industries are male.

Figure 5: Gender by type of industry

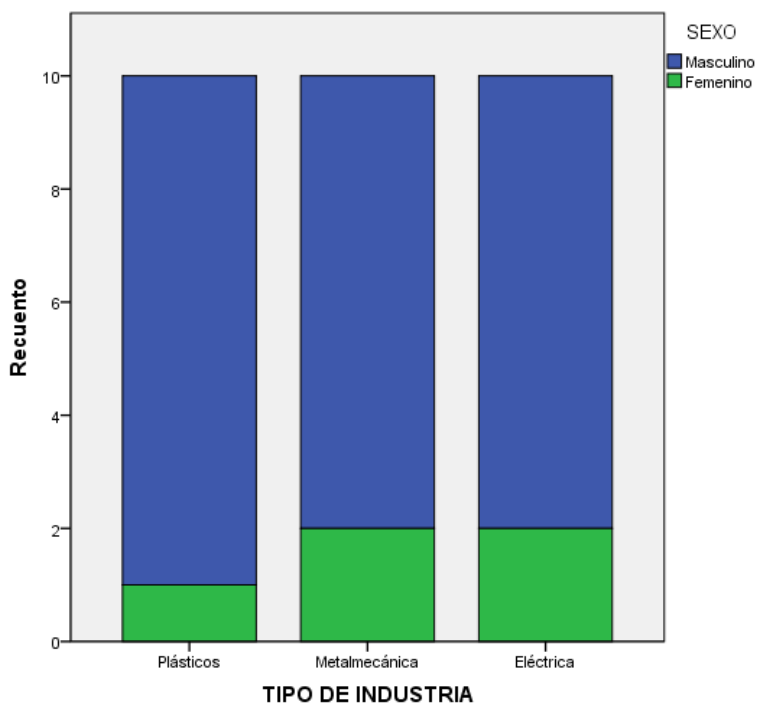

Figure 6 shows that the study participants for both the plastics and metalworking industries are under forty years old, in the electrical industry there were personnel of various ages, including over fifty years.

Figure 6: Age by type of industry

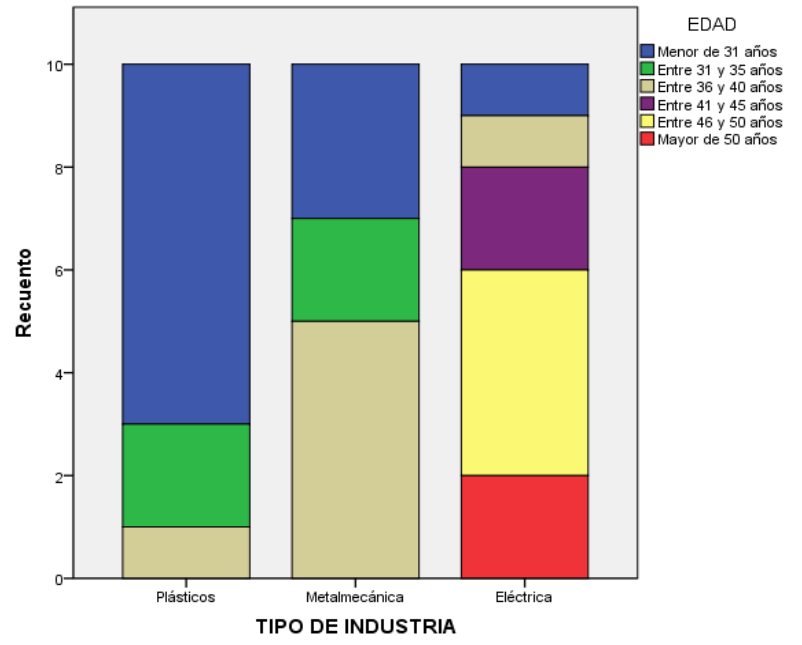

\subsection{DESCRIPTIVE STATISTICAL ANALYSIS OF THE STUDY}

The quantitative analysis was carried out based on the responses to the questionnaire of the research instrument that respond to a six-point Likert-type scale that ranges from 1 (completely disagree) to 6 (completely agree). For a specific question or a score of an entire category, a score greater than five 
is interpreted as an learning organization, a score between four and five can be interpreted as positive and that the organization has the possibility of becoming a learning organization, a score less than four indicates that the organization should evaluate its organizational policies and practices and consider whether they want to become a learning organization to stay competitive in the globalized market.

The categories or dimensions of learning organizations applied to the industrial sector of the city of Lima, considered seven organizational factors and managerial practices; and, the statistics of the mean (M) and the standard deviation (SD) were used to evaluate the data from questions one to thirty-one individually and within their respective categories. Then, a score or total index was obtained by type of industry that represents their current state in relation to the learning organization model that can be seen in table 2.

Table 2: Position of the organizational factors and management practices of the learning organization by type of industry

\begin{tabular}{|c|c|c|c|c|c|c|}
\hline \multirow{2}{*}{ CATEGORY } & \multicolumn{7}{|c|}{ INDUSTRY TYPE } \\
\cline { 2 - 7 } & \multicolumn{2}{|c|}{ PLASTICS } & \multicolumn{2}{c|}{ METALWORKING } & \multicolumn{2}{c|}{ ELECTRICAL } \\
\cline { 2 - 7 } & Score & Position & Score & Position & Score & Position \\
\hline Shared mission and vision & 4.25 & 2 & 4.33 & 1 & 4.43 & 1 \\
\hline $\begin{array}{c}\text { Mental models and } \\
\text { organizational culture }\end{array}$ & 4.10 & 4 & 4.05 & 5 & 3.95 & 2 \\
\hline $\begin{array}{c}\text { Teamwork and learning } \\
\text { Shared knowledge }\end{array}$ & 4.00 & 6 & 4.27 & 3 & 3.63 & 5 \\
\hline $\begin{array}{c}\text { Systemic thinking } \\
\text { Personal dominance and } \\
\text { leadership }\end{array}$ & 4.08 & 3 & 3.85 & 6 & 3.53 & 7 \\
\hline $\begin{array}{c}\text { Total Learning } \\
\text { Organization Index: }\end{array}$ & $\mathbf{4 . 1 4}$ & & 4.15 & 4 & 3.68 & 3 \\
\hline $\begin{array}{c}\text { Competencies and skills of the } \\
\text { Staff }\end{array}$ & 4.35 & 1 & 4.3 & 2 & 3.65 & 4 \\
\hline
\end{tabular}

Table 3 shows that using a significance level of 0.05 , the probability of the Kruskal-Wallis statistic for the total index of learning organization that measures the current state of the industrial organizations studied with respect to the learning organization model, is 0.001 , which is less than the significance level of 0.05 , so the null hypothesis is rejected, obtaining an affirmative answer to the statement that the level of the industrial companies studied is not significant according to the learning organization model.

\section{DISCUSSION}

For the discussion of results, it is considered that industrial companies that have a total index greater than five possess all the characteristics to be called learning organizations; those that are between 
four and five, have the conditions to transform into learning organizations and those that have scores below four, need to re-evaluate their organizational model and decide if they want to become a learning organization and consequently propose substantial changes within them.

From the results, it can be seen that none of the industries evaluated can be considered as a learning organization; however, two of them, plastics and metalworking, have the conditions to become one if they make the decision to do so; the management and organization model of electric company apparently is not compatible with that of the learning organization because it obtained a score of 3.77 in the total index of the learning organization, inferring that it will have to make many changes in its organizational model if you really want to become a learning organization.

Table 3: Kruskal-Wallis test of organizational factors and managerial practices of learning organization by type of industry

\begin{tabular}{|c|c|c|c|c|c|c|c|c|c|c|}
\hline \multirow{3}{*}{ CATEGORY } & \multicolumn{6}{|c|}{ INDUSTRY TYPE } & \multirow{2}{*}{\multicolumn{4}{|c|}{ CONTRAST STATISTIC }} \\
\hline & \multicolumn{2}{|c|}{ PLASTICS } & \multicolumn{2}{|c|}{$\begin{array}{c}\text { METAL- } \\
\text { WORKING }\end{array}$} & \multicolumn{2}{|c|}{ ELECTRICAL } & & & & \\
\hline & $\mathbf{N}$ & $\begin{array}{l}\text { Average } \\
\text { range }\end{array}$ & $\mathbf{N}$ & $\begin{array}{l}\text { Average } \\
\text { range }\end{array}$ & $\mathbf{N}$ & $\begin{array}{c}\text { Average } \\
\text { range }\end{array}$ & $\begin{array}{c}\text { Total } \\
\mathbf{N}\end{array}$ & $\begin{array}{l}\text { Chi- } \\
\text { square } \\
\text { d }\end{array}$ & d.f. & $\begin{array}{c}\text { Asymptotic } \\
\text { Significanc } \\
\text { e }\end{array}$ \\
\hline $\begin{array}{l}\text { Shared mission } \\
\text { and vision }\end{array}$ & 40 & 58.06 & 40 & 59.43 & 40 & 64.01 & 120 & 1 & 2 & 0.698 \\
\hline $\begin{array}{c}\text { Mental models/ } \\
\text { organizational } \\
\text { culture }\end{array}$ & 40 & 62.73 & 40 & 62.05 & 40 & 56.73 & 120 & 1 & 2 & 0.677 \\
\hline $\begin{array}{l}\text { Teamwork and } \\
\text { learning }\end{array}$ & 40 & 63.00 & 40 & 69.83 & 40 & 48.68 & 120 & 9 & 2 & 0.013 \\
\hline $\begin{array}{c}\text { Shared } \\
\text { knowledge }\end{array}$ & 40 & 71.96 & 40 & 60.16 & 40 & 49.38 & 120 & 10 & 2 & 0.008 \\
\hline $\begin{array}{c}\text { Systemic } \\
\text { thinking } \\
\end{array}$ & 40 & 63.01 & 40 & 68.71 & 40 & 49.78 & 120 & 7 & 2 & 0.031 \\
\hline $\begin{array}{c}\text { Personal } \\
\text { dominance and } \\
\text { leadership }\end{array}$ & 50 & 82.79 & 50 & 73.05 & 50 & 70.66 & 150 & 2 & 2 & 0.295 \\
\hline $\begin{array}{l}\text { Competencies } \\
\text { and skills of the } \\
\text { staff }\end{array}$ & 60 & 99.60 & 60 & 100.65 & 60 & 71.25 & 180 & 13 & 2 & 0.001 \\
\hline $\begin{array}{c}\text { Total Learning } \\
\text { Organization } \\
\text { Index: } \\
\end{array}$ & 310 & 497.64 & 310 & 491.93 & 310 & 406.93 & 930 & 24 & 2 & 0.001 \\
\hline
\end{tabular}

From the analysis of each of the categories of the learning organization, we can highlight that:

1. The shared mission and vision in the three industrial companies have the highest positive ratings, but do not exceed the required score of five to meet the requirements of a learning organization; however, they reflect that the staff is being empowered to align their personal objectives with the objectives of their organization, causing an organizational climate where innovation and creativity are promoted. The companies in the electrical and metalworking industries, both, place the shared mission and vision in first place and that of plastics second, indicating that they have taken the first step towards developing their company as a learning organization.

2. The mental models and organizational culture within the industrial companies of plastics and metalworking obtain positive scores but are not enough to be considered as learning 
organizations, however they indicate that there is the possibility of an opening to new ideas and change, that is it may be because these companies have young staff eager to experiment and develop new ideas; however, despite in the electrical this category is being ranked second, it obtains a negative score of 3.95, which could indicate that there is a need for people predisposed to learn and your company must provide them with the means and resources to learn to learn.

3. Teamwork and learning in the plastics and metalworking industry get positive marks but a bit far from what is required to be a learning organization; and, the electrical one qualifies negatively, which would require to make the personnel understand that teamwork does not disappear the individual, but is a means of personal growth where our emotional intelligence increases.

4. Shared knowledge only in the plastics industry is positive, positioning it in third place within the seven categories of learning organization; the metalworking and electrical, position in sixth and seventh place respectively; therefore, it is important that not only good practices are appreciated, but also that mechanisms and systems should be established that allow them to happen; in addition, it is important that staff have access to strategic and industry information to make timely and sound decisions.

5. Systems thinking considered the fifth discipline by Peter Senge, is the most important of all the categories; the plastics and metalworking industries place it with positive scores in fifth and fourth place respectively, the electricity industry places it in third place but with a negative score; in general, we can deduce that the three industrial companies have not yet internalized the fact that the industry is a whole rather than a set of small separate units and that the solution that we apply in one part can cause many problems to other parts of the organization.

6. The personal domain and leadership are located in the last positions in the three industrial companies, making us see that their organizational cultures differ greatly from that required by the learning organization; in a learning organization, this category is key to personal and organizational success and is as important as systems thinking in the development of an organization. Specifically, the leadership that is sought in this organizational model is that of servant, teacher and designer leadership of a creative, innovative and lifelong learning organization.

7. The competencies and skills of the personnel in both the plastics and metalworking industries are positively positioned in first and second place, but without reaching the score required by a learning organization; electricity ranks it in fourth place with a negative score. The importance of this category lies in the fact that the interest in managing people before technology and information is shown here, taking into account that the most important factor for organizational development is people.

8. The total index of the learning organization that measures the level or current state of the industrial companies studied with respect to the model of learning organizations, shows us that the plastics industry obtains the highest score (4.14), followed by metalworking (4.09) and the electric (3.77); all of them under five (5) which would be the lower limit to be considered as a learning organization; however, they have some basic conditions to set the goal of becoming industrial learning organizations.

\section{CONCLUSIONS}

The research measured and compared the dimensions or categories of the learning organization model with three representative companies of the industrial sector of the city of Lima.

The results of the research show that the postulates of the learning organization model are not internalized or are not known within the companies studied.

The dimensions or categories presented in the study describe the specific strategies, bases, measures and intervention processes that are required to become a learning organization; this should allow top management and industry leaders to take practical actions, initiatives and interventions necessary to build a industrial learning organization and measure success in achieving this result. 
All three industrial companies scored negatively in the category of personal mastery and leadership, which is a key category in conjunction with systems thinking to develop industrial learning organizations where continuous learning and growth environments are promoted.

The probability of the Kruskal-Wallis statistic is 0.001 for the total index of learning organization, which is less than the significance level of 0.05 . so the null hypothesis is rejected, obtaining an affirmative response to the statement that the level of the industrial sector of the city of Lima is not significant according to the learning organization model.

\section{ACKNOWLEDGMENTS}

I express my sincere thanks to the people who collaborated in the present study, mainly to the personnel of industrial companies: factory of plastic containers Captax-A, Metalworking Cantol and Electrical Distriluz, to whom I reiterate my deepest acknowledgments and my commitment to use the information provided only for academic purposes. 


\section{REFERENCES}

Franta, David (2012). SOF as a Learning Organization. Naval Postgraduate School, Monterrey, California, United States of America.

Goh, Swee y Ryan, Peter (2002). Learning Capability, Organization Factors and Firm Performance. Third European Conference on Organizational Knowledge, Learning and Capabilities. Athens, Greece.

Moilanen, Rail (2005). Diagnosing and Measuring Learning Organizaciones. The Learning Organization, Vol. 12, $\mathrm{N}^{\mathrm{o}} 1$, pp. 71-89.

Park, Joo Ho (2008). Validation of Senge's Learning Organization Model with Teachers of Vocational High Schools at the Seoul Megalopolis, Asia Pacific Education Review, Vol. 9, N 3, pp. 270-284.

Porras Ramírez, César A. (2010). Factores Organizacionales y Prácticas Gerenciales según Modelo de Organizaciones Inteligentes en Empresas de la Ciudad de Lima. Tesis de Maestría en Comportamiento Organizacional y Recursos Humanos, Universidad Ricardo Palma. Perú.

Senge, Peter (1990). La Quinta Disciplina. Barcelona: Ed. Granica S.A. 